\title{
Planktonic Foraminiferal Biostratigraphy of Tanjero Formation (Late Maastrichtian) in Bekhme Area, Northeastern Iraq
}

\author{
Majid M. Al-Mutwali Muthana K. Ibrahim \\ Department of Geology \\ College of Science \\ Mosul University
}

(Received 7/7/2013 , Accepted 16/1/2014)

\begin{abstract}
The biostratigraphy of Tanjero Formation has been investigated within a wellexposed section at the northern limb of Perat anticline, Bekhme area, Northeastern Iraq. The studied section consists mainly of marl, marly limestone, and sandstone. The formation conformably overlies Shiranish Formation (Late Campanian-Maastrichtian) and it is overlain unconformably by the Kolosh Formation (Paleocene). The samples of the section under investigation yielded rich and well diversified planktonic foraminiferal taxa, where 69 planktonic species belonging to 21 genera have been recognized. The detailed foraminiferal investigation permits the recognition of four well defined zones. These are from older at the base:
\end{abstract}

4. Plummerita hantkeninoides Total Range Zone.

3. Pseudoguembelina palpebra Partial Range Zone.

2. Pseudoguembelina hariaensis Interval Zone.

1. Racemiguembelina fructicosa Interval Zone.

The Planktonic zones were correlated with other zonal schemes in- and outside Iraq. They are considered to be of Late Maastrichtian age.

Keywords: biostratigraphy, Tanjero, Perat, Maastrichtian, foraminifera.

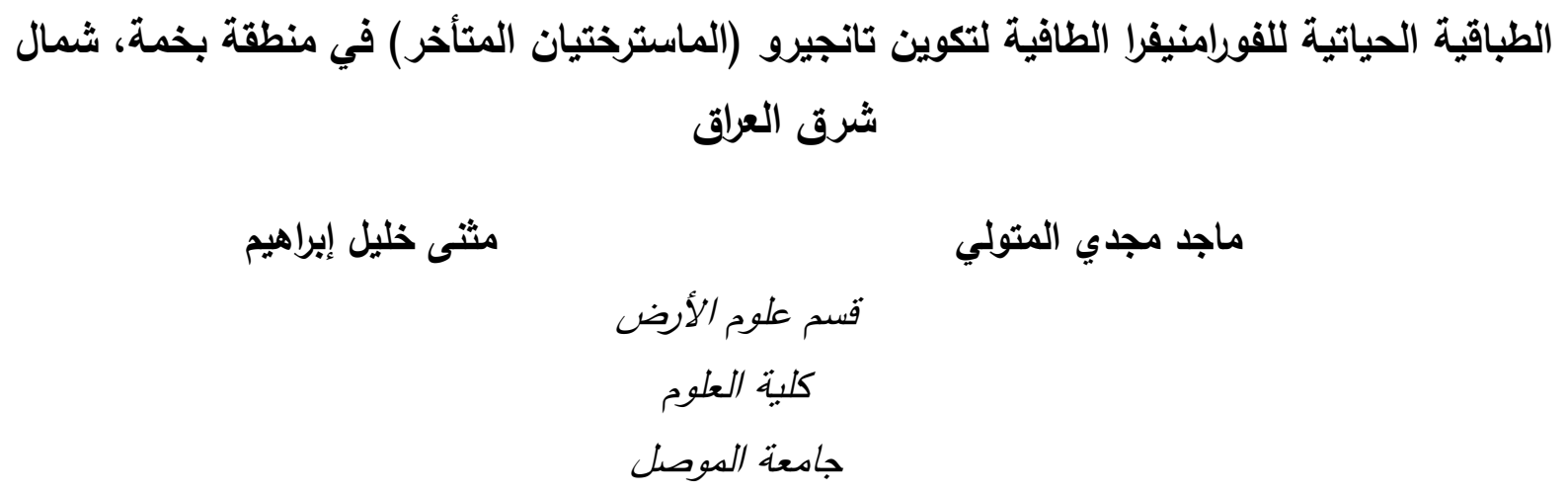




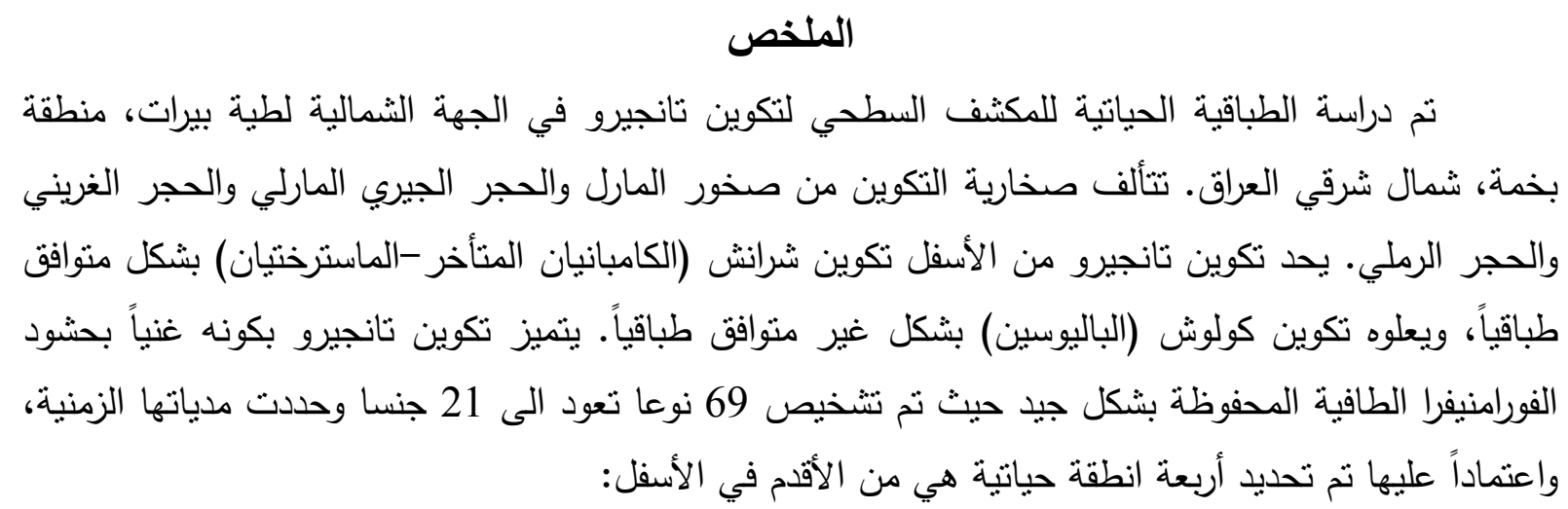

4. Plummerita hantkeninoides Total Range Zone.

3. Pseudoguembelina palpebra Partial Range Zone.

2. Pseudoguembelina hariaensis Interval Zone.

1. Racemiguembelina fructicosa Interval Zone.

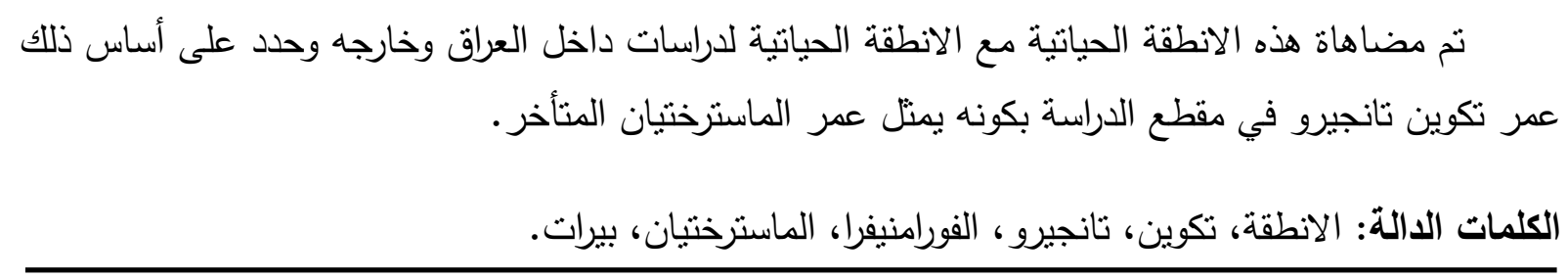

INTRODUCTION

The studied section is located at the northern limb of Perat anticline $45 \mathrm{~km}$ northeast of Aqra city. The Tanjero Formation was first defined by (Dunnington, 1952 in Bellen et al.1959) from the highly folded zone of northern Iraq, its type section located at Sirwan vally, $2 \mathrm{~km}$ to the south of Kani Karweshkan village, near Halabja town (Fig.1), on the right bank of Sirwan River (upstream of the Dialla River). It attains a thickness of m. comprises two divisions; the lower division represents pelagic marl, and occasional beds of argillaceous limestone with siltstone beds in the upper part (Bellen et al.1959), whereas, the upper division comprises silty marl, sandstone, conglomerate and sandy or silty organic detrital limestone interfingering with the Aqra limestone Formation. The thickness of the Tanjero Formation is highly variable, with a maximum thickness of about $2000 \mathrm{~m}$ between Rawanduz and Chwarta (Jassim and Goff, 2006). Abdel-Kireem (1986 a) suggests removal of the word "clastic" from the name of the formation and to place its lower part within the Shiranish Formation, and during his study, Abdel-Kireem (1986 b) subdivided the formation into three units according to the microfacies and lithofacies.

Karim $(2004,2006)$ and Karim and Surdashy (2005 a,b, 2006) investigated the basin analysis, paleocurrent, tectonic history and sequence stratigrahy of the Tanjero Formation; they indicated an unconformity in the lower part of Tanjero Formaion which was represented by about $500 \mathrm{~m}$ of boulder and gravel conglomerate. They mentioned that this conglomerate was deposited during sea-level fall (lowstand system tract). On the bases of the identified planktonic foraminiferal assemblages Sharbazheri et al. (2009) recorded five biozones (CF5-CF1) from the uppermost part of Tanjero Formation in the Sirwan valley (Sulaimani Region, NE Iraq). 
The Tanjero Formation extends into southeast Iran where it was referred to as the Maastrichtian flysch by Kent et al. (1952, in Jassim and Goff, 2006). In Turkey, the Cretaceous part of the Germav Formation is equivalent to the Tanjero Formation (Buday, 1980).

The purpose of this paper is to record the planktonic species and establishing the biostratigraphic zones and correlating them with their equivalent biozones in- and outside Iraq in order to determine the age of the studied section.

\section{LITHOSTRATIGRAPHY AND CONTACT BOUNDARIES}

Tanjero Formation in the studied section is about $230 \mathrm{~m}$ thick, its lower part mainly consists of alternation of grey marl, marl siltstone with dark grey shale and thin beds of pale grey marly limestone beds, while its upper part consists of alternation of dark grey shale or marl with olive green sandstone beds. The description of lithological constituent is shown in Fig. (2).

The lower contact of the Tanjero Formation is gradational and conformable with Shiranish Formation (Late Campanian -Early Maastrichtian), while its upper contact is unconformable with Kolosh Formation (Paleocene) (Figs.3\&4).

\section{MATERIALS AND METHODS}

Fifty-six rock samples were collected at (2-4) $\mathrm{m}$ intervals along the studied section. About $30 \mathrm{~g}$ of each sample was weighed, crushed, and boiled for $(10-30)$ hours, washed over 230 mesh sieve with tap water, dried and size-sorted using a set of sieves $(40,60,80,100,120$ mesh), then ultrasonically agitated for $(10-30)$ minutes, all specimens were picked and mounted on microslides for identification under binocular microscope.

\section{BIOSTRATIGRAPHY}

The investigation of foraminiferal assemblages within the studied section revealed that planktonic species are abundant in general within all the sequences of Tanjero Formation. Planktonic foraminifera have been used for biostratigraphic analysis for the studied section, their systematic study enabled the authors to identify sixty-nine planktonic species belonging to eighteen genera (Fig.5). The identified planktonic foraminiferal biozones were correlated with their equivalent standard biozones in other regions of the world (Figs.6\&7). Furthermore, these biozones have been correlated locally with previous studies in Iraq. The studied section can be subdivided into four biozones, these biozones are described below starting from older to younger.

\section{1- Racemiguembelina fructicosa Interval Zone (CF4) :}

Definition: This zone was introduced by Li and Keller (1998 a and b). It represents the stratigraphic range of the index species Racemiguembelina fruticosea (Egger) which precedes the appearance of Pseudoguembelina hariaensis Nederbragt.

Age: Early Late Maastrichtian. 


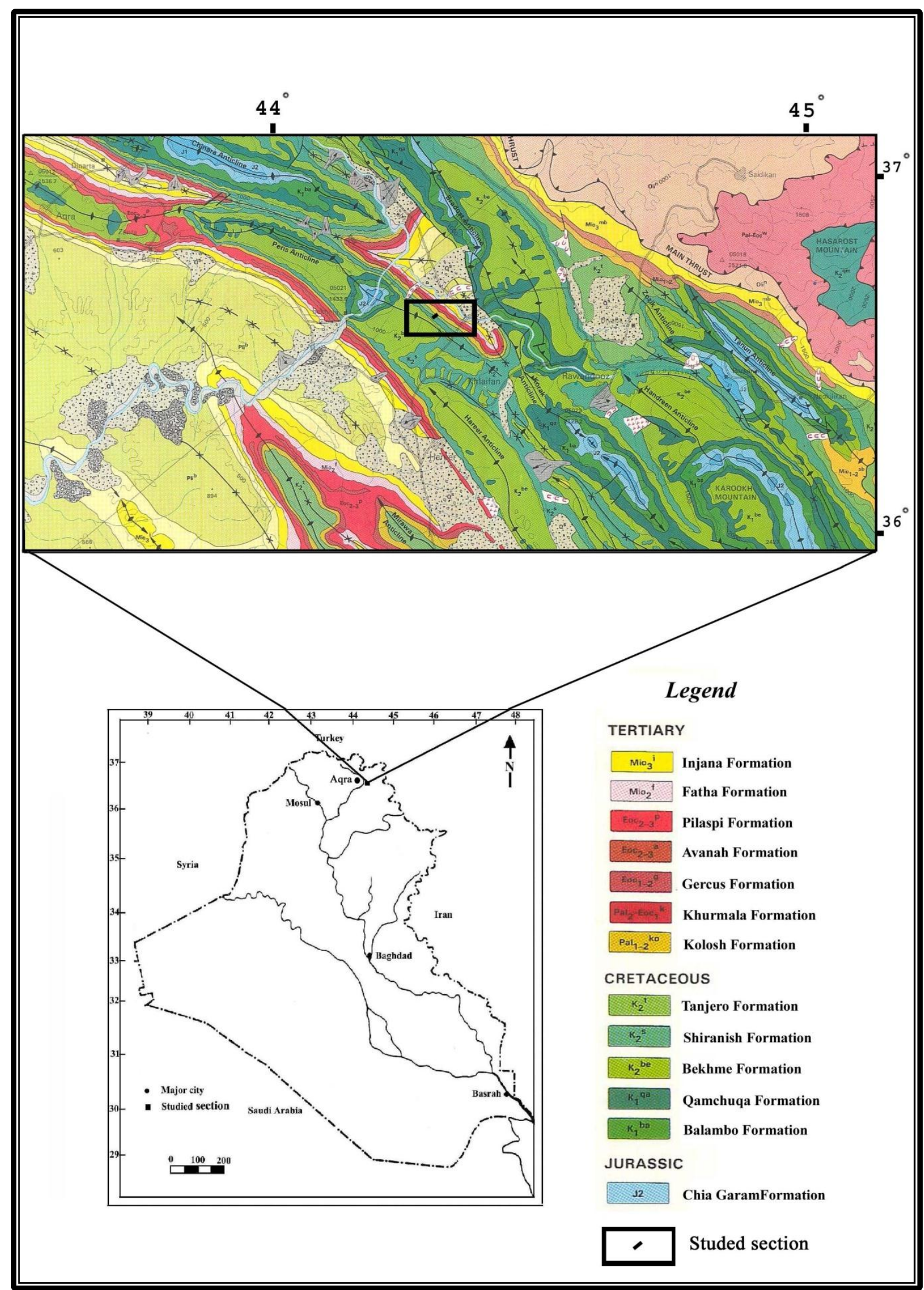

Fig.1: Location map of the studied section. 


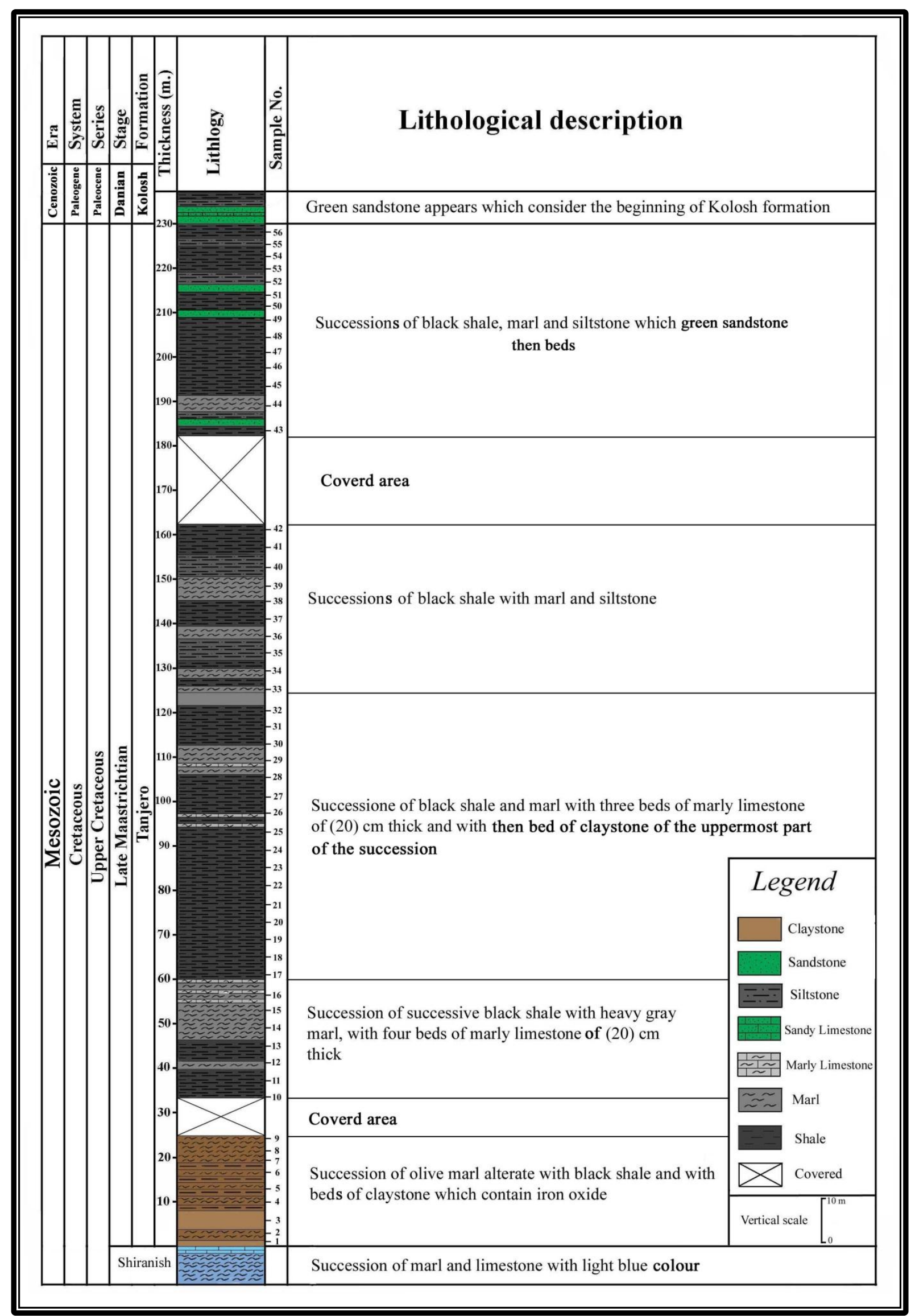

Fig.2: Lithologic description of Tanjero Formation in the studied section. 
Boundaries: The lower boundary of this zone is marked by the first appearance of Racemiguembelina fructicosa (Egger), whereas its upper boundary is marked by the first appearance of Pseudoguembelina hariaensis Nederbragt.

Thickness: $85 \mathrm{~m}$ that represented by the samples (1-23).

Correlation and Age Determination: This zone is apparently equivalent to Racemiguembelina fructicosa Zone which is described by (Li et al., 1999), (Darvishzad and Abdolulipour, 2008), (Rostami et al., 2009) of Early Late Maastrichtian age, and correlated to the upper part of Globotruncana contusa-Racemiguembelina fructicosa Zone of (Premoli Silva et al., 1998), (Arenillas et al., 2006), and (Keller et al., 2011).

Locally in Iraq, this zone is correlated with Racemiguembelina fructicosa Zone of (Sharbazheri, 2008) and (Al-Doori, 2010) which considered it of Early Late Maastrichtion age.

\section{2- Pseudoguembelina hariaensis Interval Zone (CF3) :}

Definition: This zone was originally defined by Li and Killer (1998a). The Interval zone which is represented by the stratigraphic range of the index species Pseudoguembelina hariaensis Nederbrogt between its first appearance and the last appearance of Gansserina gansseri ( Bolli )

Age: middle Late Maastrichtian

Boundaries: The lower boundary of this zone is marked by the first appearance of Pseudoguembelina hariaensis Nederbragt, whereas its upper boundary is marked by the last appearance of Gansserina gansseri ( Bolli ).

Thickness: $70 \mathrm{~m}$ represented by the samples ( $24-40)$.

Correlation and Age Determination: The present zone is equivalent to the Pseudoguembelina hariaensis Zone which is described by (Li et al., 1999), (El-Sabbagh et al, 2004), (Keller et al., 2009), (Arenillas, et al., 2006) and (Darvishzad et al., 2007), they considered it to be of middle Late Maastrichtian age.

Locally in Iraq, the zone is correlated with Pseudoguembelina hariaensis Zone of (Shanbazheri, 2008) which assigned it to the middle Late Maastrichtian age.

\section{3- Pseudoguembelina palpebra Partial range Zone (CF2) :}

Definition: This zone was defined by Li and Keller (1998 a and b), it represents the partial range of Pseudoguembelina palpebra Bronnimann and Brown between the last appearance of Gansserina gansseri ( Bolli ) and the first appearance of Plummerita hantkeninoides (Bronnimann). 


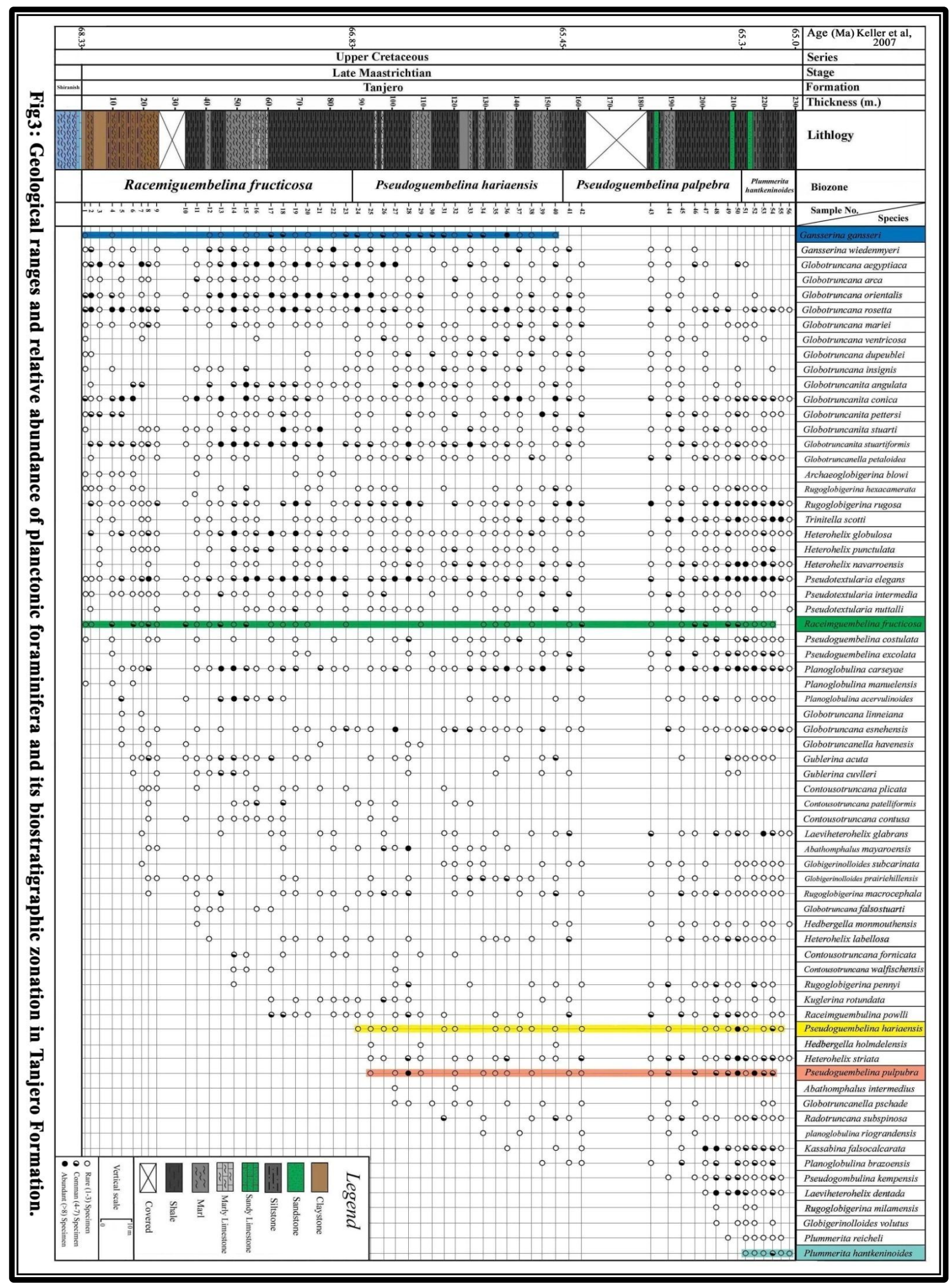




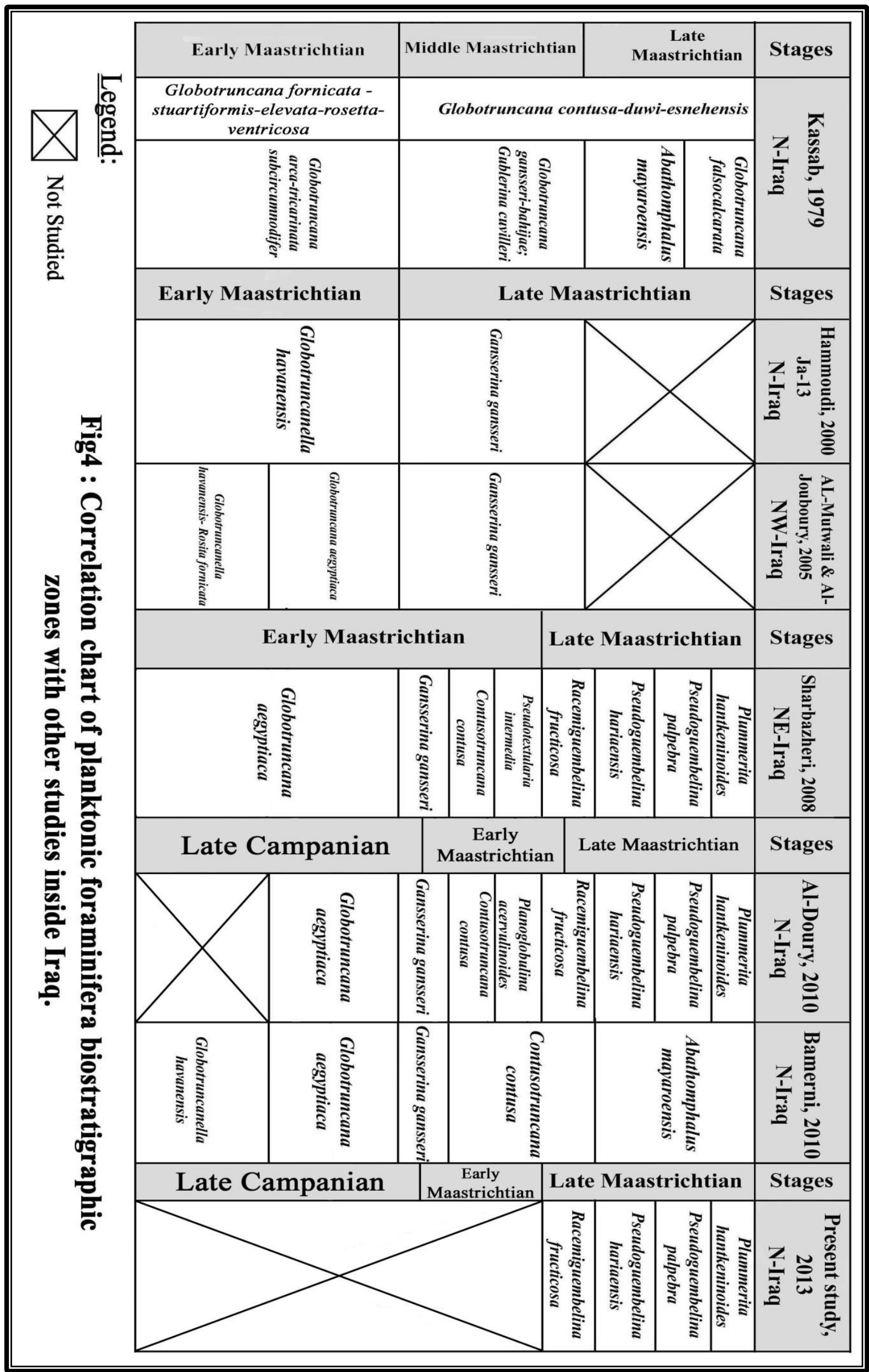




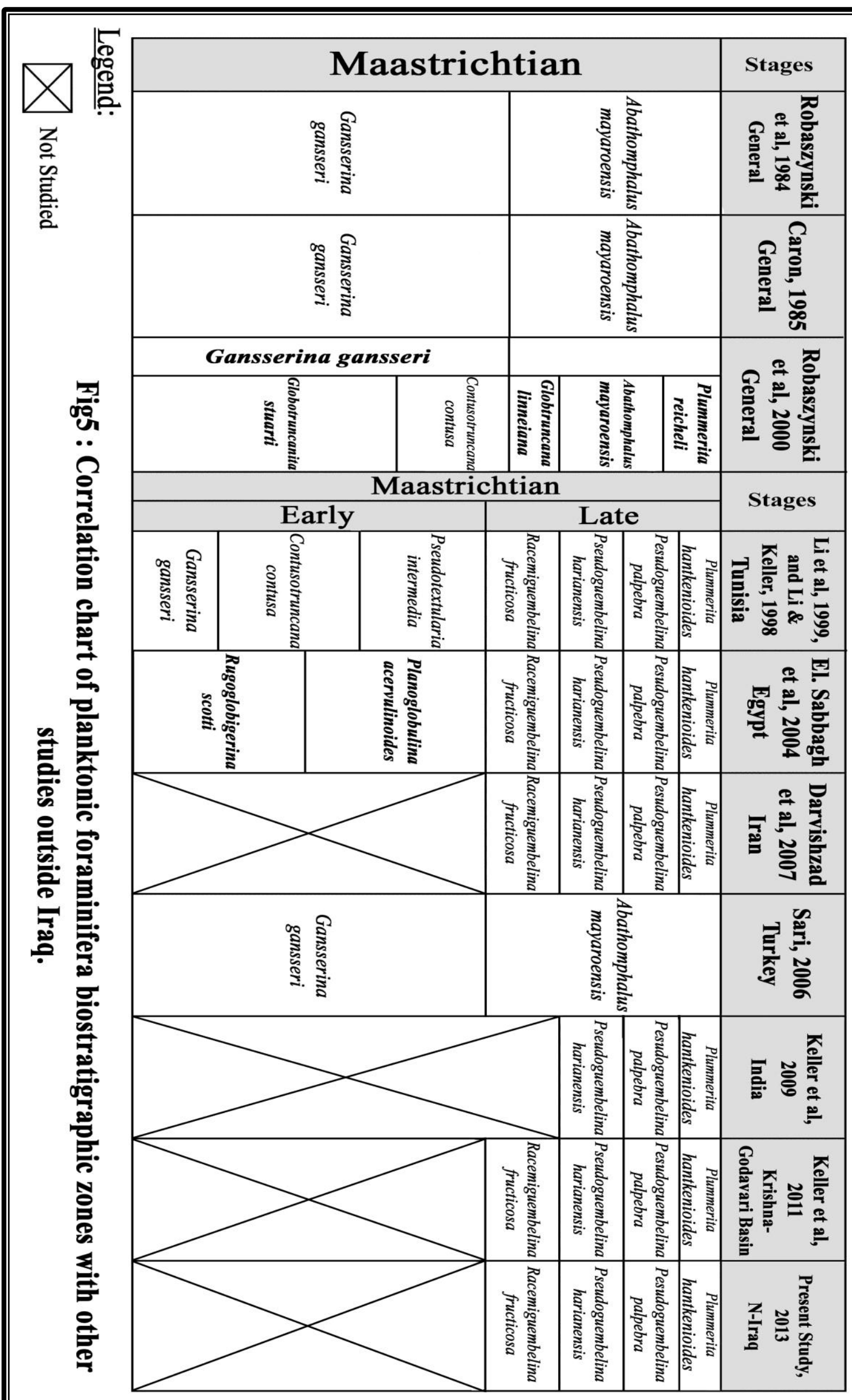


Age: Late Maastrichtian

Boundaries: The lower boundary of this zone is marked by the last appearance of Gansserina gansseri ( Bolli ), whereas its upper boundary is marked by the first appearance of Plummerita hantkeninoides (Bronnimann).

Thickness: $58 \mathrm{~m}$ that represented by the samples (41-50).

Correlation and Age Determination: The present zone is equivalent to the Pseudoguembelina palpebra Zone of (Li et al., 1999), (Darvishzad et al., 2007) and (ElSabbagh et al., 2004) who considered it of Late Maastrichtian age.

Locally in Iraq, this Zone is correlated with Pseudoguembelina palpebra Zone of (Sharbazheri, 2008) and (Al-Doori, 2010) who assigned to the Latest Maastrichtian.

\section{4- Plummerita hantkeninoides Total range Zone (CF1):}

Definition: This zone was introduced by (Pardo et al.,1996), which is defined by the total range of the nominate taxon.

Age: Latest Maastrichtian.

Boundaries: The lower boundary of this zone is marked by the first appearance of Plummerita hantkeninoides (Bronnimann), while its upper boundary is marked by its last appearance.

Thickness: $17 \mathrm{~m}$ represented by the samples (51-56).

Correlation and Age Determination: Plummerita hantkenincides is easily identified within the uppermost part of Late Maastrichtian, the range of this excellent marker species spans the youngest $300 \mathrm{kyr}$ of the Maastrichtian below the Cretaceous / Paleogene boundary (Keller et al., 2002). This zone marks the uppermost Cretaceous biozone, and its top marks the K/Pg boundary. The upper limit of this zone coincides with the mass extinction of large tropical-subtropical taxa. The present zone is equivalent to the Plummerita hantkeninoides Zone (CF1) which is described by (Li et al., 1999), (Darvishzad et al., 2007); they considered it of Latest Maastrichtian age. This zone is also correlated with the upper part of Abathomphalus mayaroensis Zone of (Robaszynski et al., 1984) (Caron, 1985), (Premoli Silva et al.,1998) (Chacon et al., 2005) of Late Maastrichtian age.

In Iraq, this zone is equivalent to the upper part of Kassabiana falsocalcarata Zone of (Kassab et al., 1986) of Late Maastrichtian age, it is equivalent to the upper part of Abathomphalus mayaroensis zone of (Bamerni, 2010), it is also correlated with Plummerita hantkeninodes Zone which is described by (Sharbazheri, 2008) of Latest Maastrichtian age. 


\section{CONCLUSION}

Planktonic foraminiferal investigation of the Upper Cretaceous Tanjero Formation in Bekhme area, northern Iraq yielded 69 species that belong to 18 genera. According to their stratigraphic range, the formation is divided into four zones. The distribusion of faunal sequence and the correlation between these zones and other zonal schemes inand outside Iraq reveals a Late Maastrichtian age for the Tanjero Formation.

\section{REFRENCES}

Abdel-Kireem, M.R., 1983. A study of the palaeoecology and bathymetry of the foraminiferal assemblages of the Shiranish Formation (Upper Cretaceous), Northeastern Iraq. Palaeogeo. Palaeoclim. Palaeoeco., Vol.43, pp.169-180.

Al-Mutwali,M.M., Al-Juboury, F.N., 2005:Petrography and Biostratigrphy of Shiranish Fomation (Late Campanian-Late Maastrichtian) in Sinjar area northwest Iraq. Raf. Jour. Sci., Vol.16, no.1, pp.152-176.

Al-Omari, F.S., Kassab, I.I. and Dawood, S., 1994. Planktonic foraminifera and biostratigraphy of Shiranish and Aaliji formations in well Mushorah (no. 1) Northwestern Iraq. Jour. Geo. Iraq, Vol. 27, no. 1, pp. 60-74.

Arenillas, I., Arz, J.A., Grajales, JM-Ni Shimura, Murillo, G-Muneton, Alrarez, W., Camargo, A.-Zonoguera, Molina, E., Rosales, C-Doniguez, 2006. Chicxulub impact events in Cretaceous/ Paleogene boundary in age: New Microplaeotological Evidence. Earth and Planetary Science Letters, Vol. 249, pp. 241254.

Bamerni, A.A., 2010. Biostratigraphy of the Shiranish Formation in the subsurface section of Khanke well no. 1 Dohuk area north Iraq. Unpublished M.Sc. Thesis, University of Mosul, Iraq (in Arabic with English abstract).

Bellen, R.C. Van, Dunnington, H.V., Wetzel, R. and Morton, D.M., 1959. Lexique Stratigraphique International. Asie, Fasc., 10a, Iraq, 333p.

Caron, M., 1985. Cretaceous planktonic foraminifera. In: Bolli, H.M., J.R. Saunders and K. Perch-Nielsen (eds.) Planktonic Stratigraphy. Cambridge Univ. Press, pp. 1786, figs37.

Chacon, B. and Chivelet, J.M., 2004. Major Paleoenvironmental changes in the Campanian to Paleocene sequence of Caravaca (subbetic zone, Spain). Journal Ibrian Geo., Vol. 31, no. 2, pp. 299-310.

Darvishzad, B. and Abdolalipour S., 2008. Campanian and Maastricthian biostratigraphy and paleoenvironment in Jorband section, north of Iran. Jour. of Sciences, Iran, Vol. 1, no. 1, pp. 1-17.

Darvishzad, B., Nejad, E.Gh., Ghourchaei, S. and Keller, G., 2007. Planktonic foraminiferal biostratigraphy and faunal turnover across the Cretaceous-Tertiary boundary in Southwestern Iran. Jour of Sciences, Iran, Vol. 18, no. 2, pp. 139-149.

Gradstein, F.M., Ogg, J.G., Smith, A.G., 2004. A geologic time scale 2004.Cambridge University Press. Cambridge, 500p.

Hammoudi, R.A., 2000. Planktonic foraminiferal biostratigraphy of the Shiranish Formation (Upper Cretacous) in Jambur well No. 13 Northern Iraq. Raf. Jour. Sci., Vol. 11, no. 4, pp. 50-58. 
Ismael, K.M., Khanaq, A.P. and Karim, K.H., 2011. Biostratigraphy of Bluish marl succession (Maastrichtian) in Sulaimanyia area, Kurdistan region, NE-Iraq. Iraqi Nat. Jour. Earth Sci., Vol.11, no.2, pp.81-99.

Jassim, S.Z. and Buday, T., In Jassim, S.Z. and Goff, J.C, 2006. Geology of Iraq. Published by Dolin, Prague and Moravian Mus. Brno, 341p.

Kassab, I.I., 1973. Planktonic foraminiferida of the Shiranish Formation type locality, Northern Iraq. Jour. Geol. Soc. Iraq, Vol. 1, pp.100-109.

Kassab, I.I., 1979. The genus Globotruncana Cushman from the Upper Cretaceous of Northern Iraq. Jour. Geol. Soc. Iraq, Vol. 12, no. 1, pp. 27-127.

Kassab, I.I.M., Al-Omari, F.S. and Al-Safawee, N.M., 1986. The Cretaceous-Tertiary boundary in Iraq (represented by the subsurface section of Sasan well no.1, NW Iraq). Jour. Geol. Iraq, Vol.19, no.2, p.73-86.

Keller, G., Adatte, T., Stinnesbeck, W., Luciani, V., Yaakoub, N. K. and Turki, D.Z. 2002. Paleoecology of the Cretaceous-Tertiary mass extinction in Planktonic foraminifera. Palaeogeo. Palaeoclim. Palaeoeco., Vol. 178, pp. 257-297.

Keller, G., Adatte, T., Tantawy, A.A., Berner, Z., Stinnesbeck, W., Stueben, D., and Leanza, H.A., 2007. High stress late Maastrichtian-early Danian palaeoenvironment in the Neuquen basin, Argentina. Cretac. Res.Vol. 28, pp. 1-22.

Keller, G., Abramovich, S., Berner, Z., and Adatte T., 2009. Biotic effects of the Chicxulub impact, K-T catastrophe and sea level change in Texas.Palaeogeography,Palaeoclimatology,Palaeoecology, Vol. 271, pp.52-68.

Keller, G., Bhowmick, P.K., Upadhyay, H., Dave, A., Reddy, A.N., Jaiprakash, B.C., and Adatte, T., 2011. Deccan volcamism linked to the Cretaceous-Tertiary boundary mass extinction: New evidence from ONGC wells in the KrishnaGodavari basin. Jour. Geo. Soc. India, Vol. 78, pp.399-428.

Keller, G., Khosla, S.C., Sharma, R., Khosla, A., Bajpai, S, and Adatte, T., 2009. Early Danian planktonic foraminifera from Cretaceous-Tertiary intertrappean beds at Jhilmili, Chhindwara district. Madhya Pradesh India., Vol. 39. pp. 40-55.

Li, L., Keller, G. and Stinnesbeck,W., 1999. The Late Campanian and Maastrichtian in northwestern Tunisia: Palaeoenvironment inferences from lithology, macrofauna and benthic foraminifera. Cretaceous Research, Vol. 20, issue2, p. 231-252.

Pardo, A., Ortiz, N. and Keller, G., 1996. Latest Maastrichtian foraminiferal turnover and its environmental implications at Agost, Spain. In: Macleod, N and Keller, G. (eds.), Cretaceous-Tertiary Mass Extinction: Biotic and Environmental changes. Norton, W. \& Co., New York, pp.139-172.

Robaszynski, F., Caron, M., Gonzalez, D.J.M. and Wonders, A.A.H., 1984. Atlas of late Cretaceous Globotruncanids. Revue Micropal., Vol.26, no. (3-4), pp.145-305.

Robaszynski, F., Donoso, J.M., Linares, D., Caron, M., Dupuis, C., Dhondt, A., and Gartiner, S., 2000. The Upper Cretaceous of the Kalaat Senan region, central Tunisia. Integrated Litho-Biostratigraphy mased on Ammonites, planktonic Foraminifera and Nannofossils zones form upper Turonian to Maastrichtian. Centers Rech. Explor-Prod,v.22,no.2, pp.359-490,24pls.,51figs.

Rostami, M.A., Balmaki, B., Ardestani, M.Sh., Kohansal, E., 2009. Biostratigraphy and assigning the paleosalinity by using Echinocorys and Planktonic foraminifera at Upper Maastrichtian in Jorband Section, Central Albroz, Iran, Nature Preceding doi., 10.1038/npre.3699.1, pp.1-7. 
Sharbazheri, Kh.M.I., 2008. Biostratigraphy and paleoecology of Cretaceous/ Tertiary boundary in the Sulaimania region, NE Iraq. Unpublished $\mathrm{PhD}$ Thesis, University of Sulaimania, Iraq, 200p.

Sharbazheri, Kh. M.I., 2010: Planktonic foraminiferal Biostratigraphy of the reddish to pale brown transitional succession (Upper Cretaceous) in Smaquli area, Northeast Iraq, Kurdistan region. Iraqi Bulletin of Geology and Mining, Vol.6, no.1, pp.120. 


\section{PLATE 1}

Fig. 1: Heterohelix globulosa (Ehrenberg). Sample No. 49.

Fig. 2: Heterohelix labellosa Nederbragt. Sample No. 25.

Fig. 3: Heterohelix striata (Ehrenberg). Sample No. 51.

Fig. 4: Laeviheterohelix dantata (Stenestad). Sample No. 50.

Fig. 5: Laeviheterohelix glabrans (Cushman). Sample No. 50.

Fig. 6: Planoglobulina acervulinoides (Egger). Sample No. 14.

Fig. 7: Planoglobulina brazoensis Martin. Sample No. 50.

Fig. 8: Planoglobulina carseyae Plummer. Sample No. 49.

Fig. 9: Pseudotextularia intermedia Deklasz. Sample No. 27.

Fig. 10: Racemiguembelina fructicosa(Egger). Sample No. 10.

Fig. 11: Gublerina cuvillieri Kikoine. Sample No. 14.

Fig. 12: Pseudoguembelina costulata (Cushman). Sample No. 51. 


\section{PLATE 1}

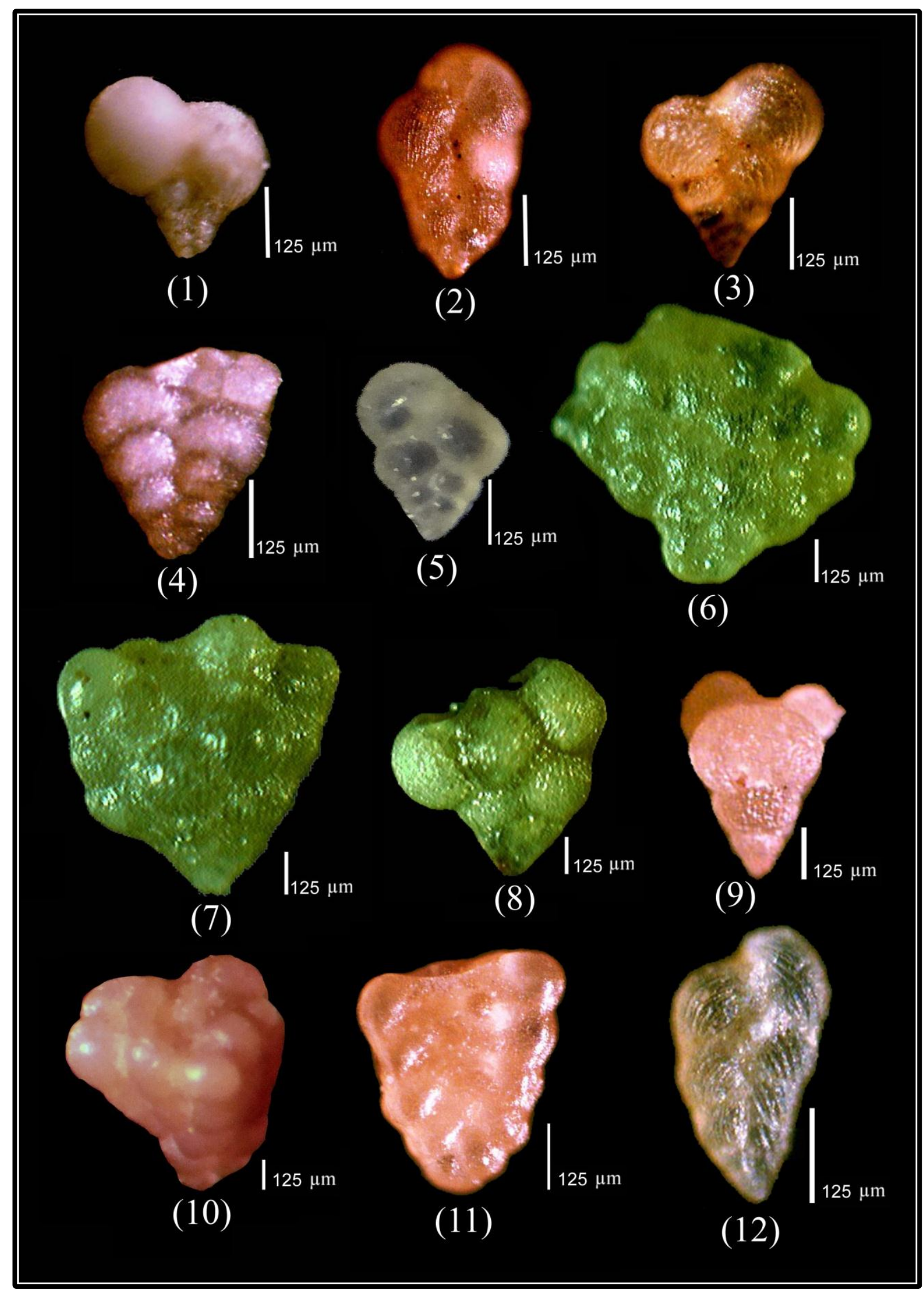




\section{PLATE 2}

Fig. 1: Pseudoguembelina hariaensis Nederbragt. Sample No. 35.

Fig. 2: Pseudoguembelina palpebra Brönnimann \& Brown. Sample No. 48.

Fig. 3a: Globigerinelloides subcarinata Bronnimann. Umbilical side. sample No. 51.

Fig. 3b: Globigerinelloides subcarinata Bronnimann. Spiral side. sample No. 51.

Fig. 4a: Gansserina gansseri (Bolli). Spiral side. Sample No. 17.

Fig. 4b: Gansserina gansseri (Bolli). Side view. Sample No. 17.

Fig. 4c: Gansserina gansseri (Bolli). Umbilical side. Sample No. 17.

Fig. 5a: Globotruncana aegypyiaca Nakkady. Spiral side. Sample No. 14.

Fig. 5b: Globotruncana aegyptiaca Nakkady. Side view Sample No. 14.

Fig. 5c: Globotruncana aegyptiaca Nakkady. Umbilical side. Sample No. 14.

Fig. 6a: Globotruncana dupeublei Caron et al.. Spiral side. Sample No. 28.

Fig. 6b: Globotruncana dupeublei Caron et al.. Side view. Sample No. 28.

Fig. 6c: Globotruncana dupeublei Caron et al.. Umbilical side. Sample No. 28. 


\section{PLATE 2}

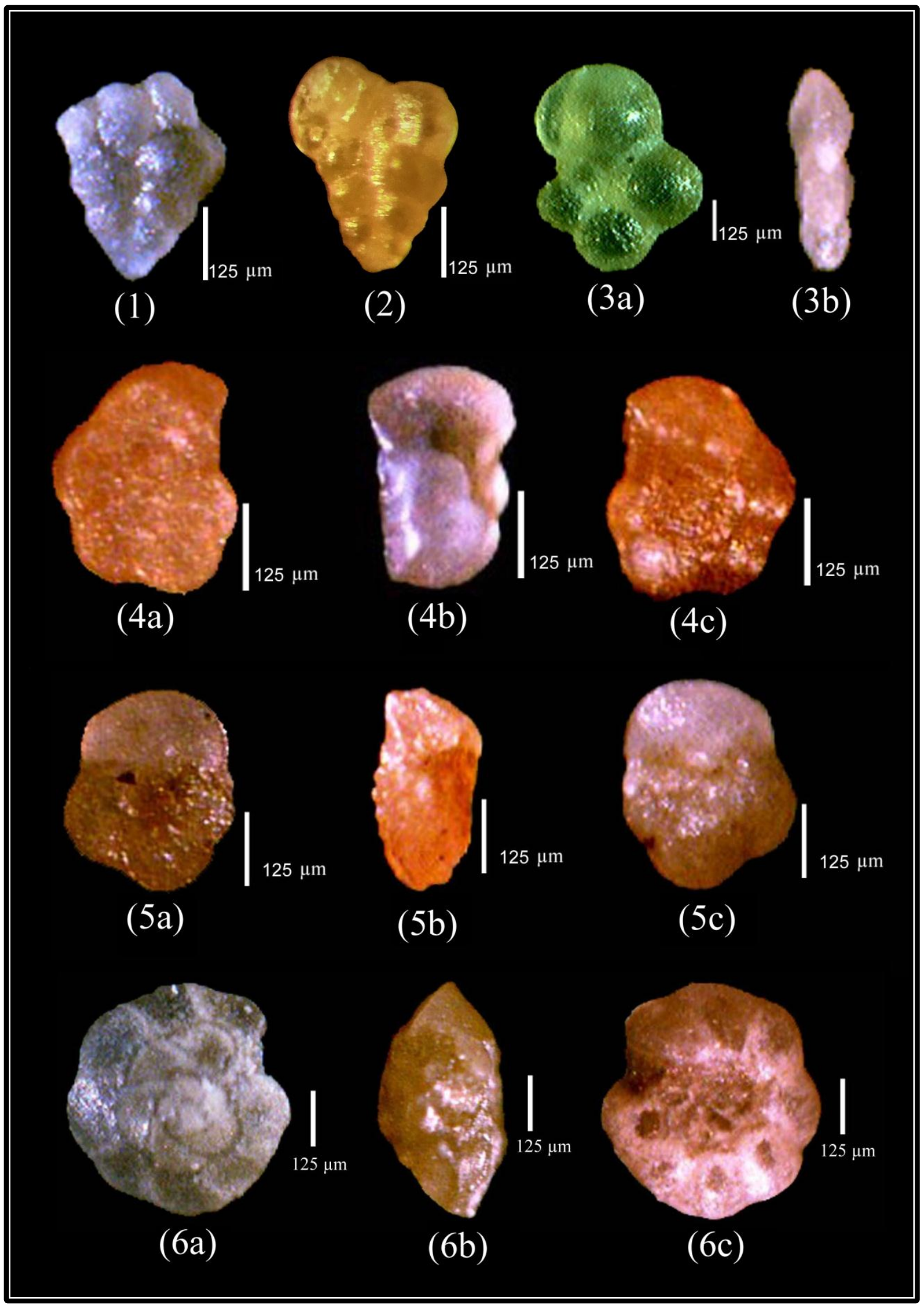




\section{PLATE 3}

Fig. 1a: Globotruncana rosetta (Carsey). Spiral side. Sample No. 36.

Fig. 1b: Globotruncana rosetta (Carsey). Side view. Sample No. 36.

Fig. 1c: Globotruncana rosetta (Carsey). Umbilical side. Sample No. 36.

Fig. 2a: Globotruncanita angulata (Tilev). Spiral side. Sample No. 6.

Fig. 2b: Globotruncanita angulata (Tilev). Side view. Sample No. 6.

Fig. 2c: Globotruncanita angulata (Tilev). Umbilical side. Sample No. 6.

Fig. 3a: Globotruncanita conica (White). Spiral side. Sample No. 27.

Fig. 3b: Globotruncanita conica (White). Side view. Sample No. 27.

Fig. 3c: Globotruncanita conica (White). Umbilical side. Sample No. 27.

Fig. 4a: Globotruncanita stuarti (de Lapparent). Spiral side. Sample No. 18.

Fig. 4b: Globotruncanita stuarti (de Lapparent). Side view. Sample No. 18.

Fig. 4c: Globotruncanita stuarti (de Lapparent). Umbilical side. Sample No. 18. 


\section{PLATE 3}

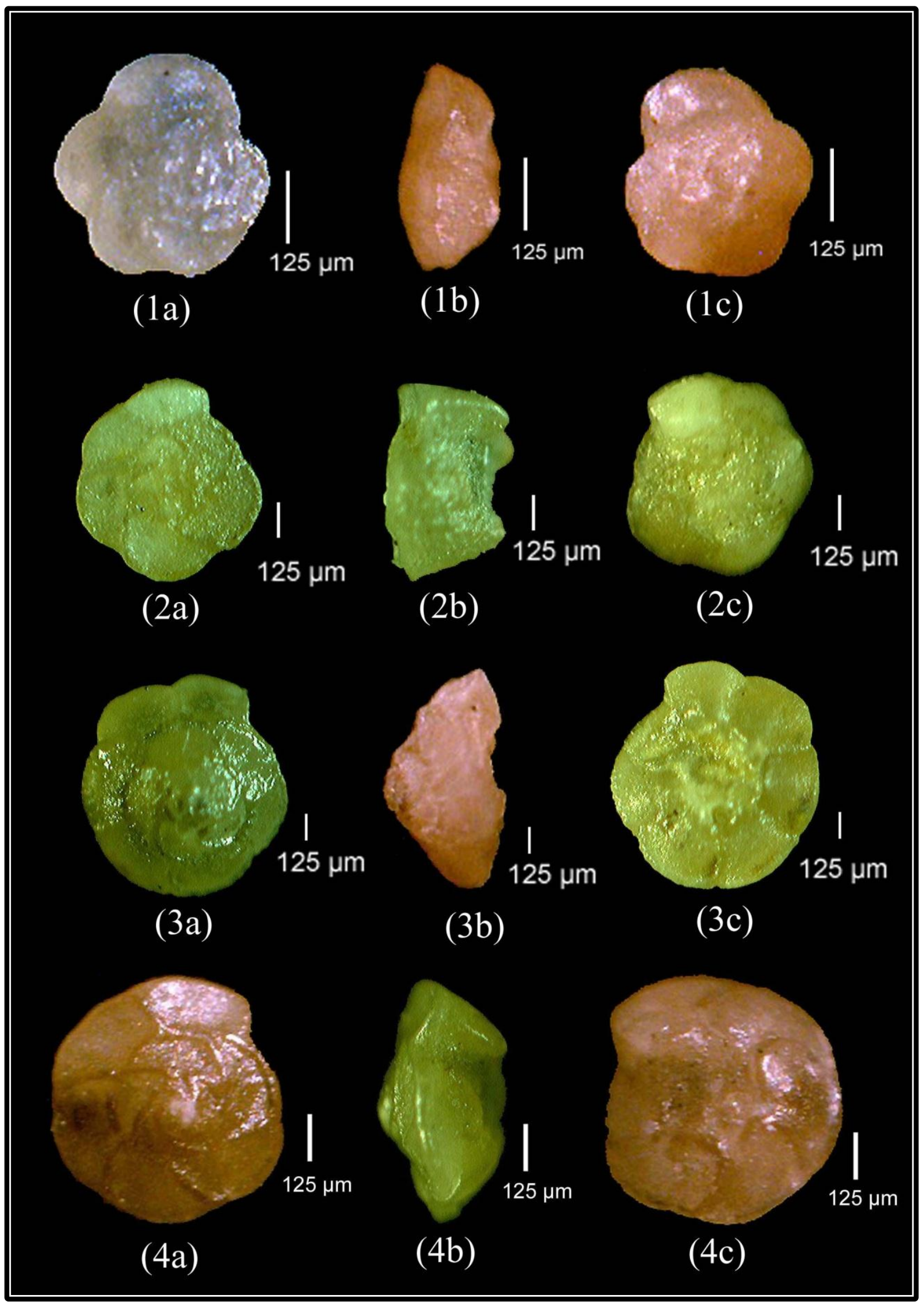




\section{PLATE 4}

Fig. 1a: Abathomphalus mayaroensis (Bolli). Spiral side. Sample No. 28.

Fig. 1b: Abathomphalus mayaroensis (Bolli). Side view. Sample No. 28.

Fig. 1c: Abathomphalus mayaroensis (Bolli). Umbilical side. Sample No. 28.

Fig. 2a: Plummerita hantkeninoides (Bronnimann). Spiral side. Sample No. 52.

Fig. 2a: Plummerita hantkeninoides (Bronnimann). Side view. Sample No. 52.

Fig. 2a: Plummerita hantkeninoides (Bronnimann). Umbilical side. Sample No. 52.

Fig. 3a: Rugoglobigerina macrocephala Brönnimann. Spiral side. Sample No. 48.

Fig. 3b: Rugoglobigerina macrocephala Brönnimann. Spiral side. Sample No. 48.

Fig. 3c: Rugoglobigerina macrocephala Brönnimann. Umbilical side. Sample No. 48.

Fig. 4a: Rugoglobigerina rugosa (Plummer). Spiral side. Sample No. 47. Fig. 4b: Rugoglobigerina rugosa (Plummer). Side view. Sample No. 47.

Fig. 4c: Rugoglobigerina rugosa (Plummer). Umbilical side. Sample No. 47. 


\section{PLATE 4}

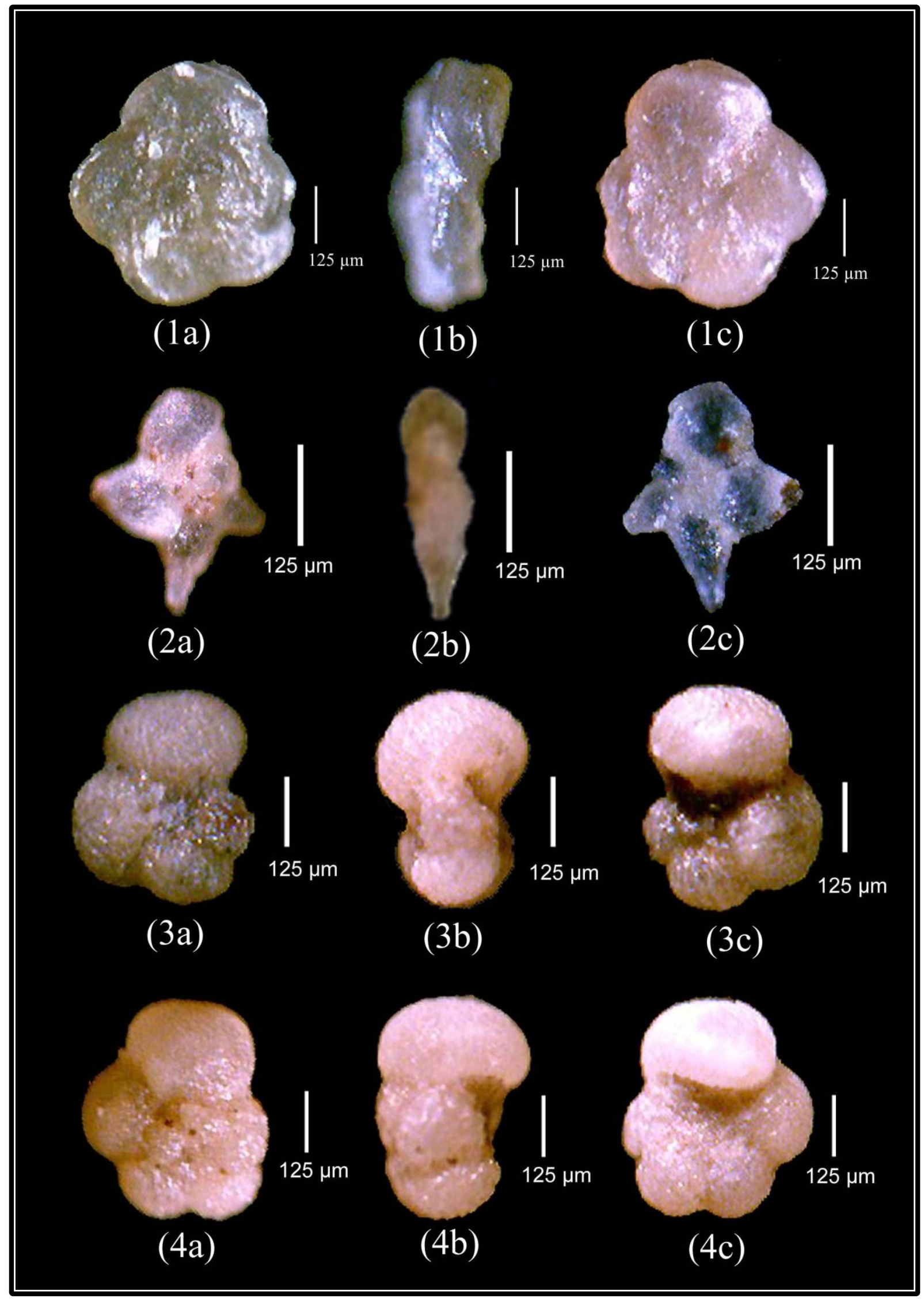

